\title{
Economic and social upgrading in global production networks: A new paradigm for a changing world
}

\author{
Stephanie BARRIENTOS,* Gary GEREFFI** \\ and Arianna ROSSI***
}

\begin{abstract}
A key challenge in promoting decent work worldwide is how to improve the position of both firms and workers in value chains and global production networks driven by lead firms. This article develops a framework for analysing the linkages between the economic upgrading of firms and the social upgrading of workers. Drawing on studies which indicate that firm upgrading does not necessarily lead to improvements for workers, with a particular focus on the Moroccan garment industry, it outlines different trajectories and scenarios to provide a better understanding of the relationship between economic and social upgrading.
\end{abstract}

significant proportion of trade now takes place through coordinated value chains in which lead firms play a dominant role globally and locally. The outsourcing of production by Northern buyers has stimulated the growth of manufacturing, agriculture and service industries in the South. It has promoted regional and global production networks (GPNs) that have opened up supply opportunities in new and expanding markets, including China, India and Brazil. Firms engaged in GPNs have opportunities for economic upgrading through engaging in higher value production or repositioning themselves within value chains. However, they also face challenges meeting buyers' commercial demands and quality standards, which smaller and less efficient producers find hard to satisfy.

The expansion of global production in labour-intensive industries has been an important source of employment generation. Many of the new jobs have been filled by women and migrant workers who previously had difficulty accessing

* Senior Lecturer, Institute for Development Policy and Management, and Associate Director, Brooks World Poverty Institute, University of Manchester, email: s.barrientos@ manchester.ac.uk. ** Professor of Sociology and Director, Center on Globalization, Governance \& Competitiveness, Duke University, email: ggere@soc.duke.edu. *** Technical Officer, Better Work programme, ILO, email: rossi@ilo.org. The authors wish to thank Joonkoo Lee, Anne Posthuma and two anonymous referees for their helpful comments on this article.

Responsibility for opinions expressed in signed articles rests solely with their authors, and publication does not constitute an endorsement by the ILO. 
this type of wage employment, and they have provided new sources of income for poorer households (Raworth, 2004; Barrientos, Dolan and Tallontire, 2003). Where such employment is regular and generates better rights and protection for workers, it can promote social upgrading and decent work. The demand for higher quality standards often requires skilling of at least some workers and provision of better employment conditions. But for many workers, this is not the outcome. Much GPN employment is insecure and unprotected, and ensuring decent work for more vulnerable workers poses significant problems.

Indeed, a key challenge is how to improve the position of both firms and workers within GPNs. This is particularly important in developing countries, where firms and workers are increasingly integrated into regional or global production systems involving many locations. Accordingly, this article explores the obstacles and opportunities for promoting decent work through economic and social upgrading in the context of GPNs. It draws on previous empirical studies in which we examined each type of upgrading/downgrading separately. Based on these insights, it aims to advance a more integrated analytical framework linking economic and social upgrading/downgrading. Rossi's (2011) case study of the Moroccan garment industry provides an early application of this framework, which can inform much-needed future research on the linkages between economic and social upgrading. This research indicates that firms' economic upgrading can, but does not necessarily, lead to improvements for workers. Therefore, the central question considered here is: under what circumstances can both firms and workers gain from a process of upgrading?

The remainder of this article is organized into five sections. The first examines the literatures on global value chains, production networks and labour economics. It addresses the separation between the firm and worker levels of analysis in the context of GPNs, where production and employment decisions are influenced not only by local markets, but also by foreign buyers and their agents. The second section introduces the concepts of economic and social upgrading as means of assessing improvements for firms and workers engaged in GPNs. The third section develops a framework for assessing the linkages between economic and social upgrading based on type of value chain and type of work. It then examines some of the opportunities and challenges those linkages present, given that regular and irregular workers have very different levels of access to employerbased channels for promoting their rights, protection and voice. The fourth section considers some of the trajectories (and mixed outcomes) that can be pursued through economic and social upgrading or downgrading. The fifth offers concluding remarks.

\section{Changing patterns of trade, production and employment}

The rise of international outsourcing through global and regional production networks requires a shift in our analytical approach. Nowadays, expanded networks of firms and workers in Africa, Asia and Latin America are linked to 
the global economy. These range from large commercial factories and farms, through subcontractors and outgrowers, to smallholders and homeworkers. Global production and services account for a growing number of workers recruited into export-oriented industries in developing countries, such as apparel, footwear and agriculture (Gereffi, 1999 and 2006). These changing structures of trade, production and employment have been defined in different ways, which should be addressed from the outset.

Global value chain (GVC) analysis initially focused on the commercial dynamics between firms in different segments of the production chain. A seminal distinction was made between producer-driven and buyer-driven commodity chains (Gereffi, 1994). In producer-driven chains, production was controlled by integrated transnational manufacturers in capital- and technology-intensive industries, such as automobiles and advanced electronics. Buyer-driven chains evolved as developed country firms set up global sourcing networks to procure labour-intensive consumer goods from low-cost suppliers in Asia, Latin America and Africa. A novel feature of buyer-driven chains was that their lead firms were large retailers (such as Walmart and Tesco) and global brands or marketers (such as Nike and Gap). They had no direct ownership of factories, but increasing control over production through their ability to set prices, product specifications, process standards and delivery schedules in their supply chains (Dolan and Humphrey, 2000 and 2004). They also contributed to the institutionalization of demand-responsive economies with lead firms or agents based in developing countries, such as the Republic of Korea and Taiwan (China) (Hamilton and Gereffi, 2009). The expansion of GVCs has encompassed not only the agricultural and manufacturing sectors, but also global services, such as tourism, logistics, finance and business process outsourcing located in diverse socio-economic contexts across countries (Gereffi, Humphrey and Sturgeon, 2005; Staritz, Gereffi and Cattaneo, 2011).

The growing complexity and pervasiveness of global production and trade led to diverse formulations. GVC analysis drew attention to the role of value creation, value differentiation, and value capture in a coordinated process of production, distribution and retail (Lee, 2010; Bair, 2009; Gereffi, 2005; Gereffi and Kaplinsky, 2001). A parallel literature around GPNs placed more emphasis on the institutional or social context of interconnected commercial operations (Henderson et al., 2002). GPN analysis examined not only the interaction between lead firms and suppliers, but also the whole range of actors that contribute to influencing and shaping global production, such as national governments, multilateral organizations, and international trade unions and nongovernmental organizations (NGOs) (Bair, 2009, p. 4; Hess and Yeung, 2006). A GPN approach also emphasizes the social and institutional embeddedness of production, and power relations between actors, which vary as sourcing is spread across multiple developing countries.

Consideration of workers in GPNs has so far been limited, particularly in academic studies (Pegler and Knorringa, 2007; Barrientos, Dolan and Tallontire, 2003; Cumbers, Nativel and Routledge, 2008; Coe and Jordhus-Lier, 2011; Rossi, 2011). In the early GVC/GPN literature, the focus was on the firm, with labour 
treated primarily as an endogenous factor of production. Analysis of labour in value chains has largely been restricted to the aggregate number of workers at different nodes of the chain, with an occasional breakdown of employment by job category, skill or sex. The exceptions have mainly been case studies examining conditions of employment, protection and the rights of workers in GPNs. These have included the study of female workers (Hale and Wills, 2005), homeworkers (McCormick and Schmitz, 2002), smallholders (ETI, 2005), social protection of informal workers (Barrientos and Ware Barrientos, 2002) and trade unions (Miller, Turner and Grinter, 2011; Cumbers, Nativel and Routledge, 2008). NGOs have also engaged in research on poor working conditions and lack of employment rights among workers in value chains as a basis for campaigns and advocacy in relation to high-profile global buyers and their suppliers (Raworth, 2004; Oxfam International, 2010; ActionAid International, 2005; Wilde and de Hann, 2006; CIVIDEP-India/SOMO, 2009; Clean Clothes Campaign, 2009; Raworth and Kidder, 2009). However, there has been a disjuncture in the literature between a "firm focus" that treats labour as a factor of production, and a "rights focus" on the conditions and entitlements of workers.

To bridge this divide between the economic and social analysis of labour, we seek to integrate workers as productive and social agents into the changing dynamics of GPNs in developing countries. Our aim is to gain a better understanding of how economic and social upgrading play out for firms and workers, and how strategies for upgrading that benefit both firms and workers can be enhanced. In order to capture the different dimensions of labour, we approach the analysis of labour in the context of GPNs from two perspectives. The first sees labour as a productive factor: Conventional economic theory views labour as a factor of production, based on the marginal productivity of labour and labour costs within individual firms or labour markets. An important assumption here is that firms need to produce at the lowest possible marginal cost to remain competitive. However, this does not fully take into account the role of labour within the context of GVCs/GPNs, where an important commercial driver is the need to meet both cost pressures and quality standards (Barrientos and Kritzinger, 2004). This affects the work intensity and skill levels of the labour required at different nodes within GPNs. In addition to the need to meet the requirements of lead firms and buyers, this is also determined by local labour market conditions (availability of different types of workers).

The second perspective sees labour as socially embedded: Viewing workers as social agents looks beyond their role as factors of production, highlighting them as human beings with capabilities and entitlements (Sen, 1999 and 2000). Workers have rights under national legislation and international conventions, such as the core Conventions of the ILO. Wage labourers are indeed largely dependent on access to rights that enhance their well-being, and such access, in turn, can be affected either positively or negatively by participation in GPNs. Beyond the workplace, the well-being of workers and their dependants is affected by formal and informal social protection networks and strategies sustained by governments and communities. 
The analysis of GPNs allows for examination of both the narrower commercial dimension of labour used within value chains and the broader, socially embedded dimension of work (often as a gendered process) in the globalization of production and services. However, the GPN context brings a number of challenges for the analysis of upgrading. Firstly, the quantity and type of employment by individual supplier firms are affected not only by national labour market conditions, but also by requirements dictated by foreign agents or buyers (in relation to product quality, price and delivery schedules). Secondly, the quality of employment is mediated not only by the national framework of labour legislation, inspection and industrial relations, but also by the codes of conduct of large global buyers and a private system of monitoring and auditing. In this context, the relationship between the quantity and quality of employment is poorly understood. ${ }^{1}$ An important question is whether it is possible simultaneously to improve both the quantity and quality of employment in GPNs. And if so, under what circumstances might this occur, and what strategies could promote this? To examine further the linkages between the two, we now explore the concepts of economic and social upgrading and how they can contribute to a broader strategy of development.

\section{Defining economic and social upgrading}

Upgrading has been identified as a move to higher value added activities in production, to improve technology, knowledge and skills, and to increase the benefits or profits deriving from participation in GPNs (Gereffi, 2005, pp. 171-175). Initially, the GVC literature focused on labour-intensive manufacturing, such as garments, footwear and toys. These industries exemplified the outsourcing of labour-intensive segments of production to low-wage countries; and their study used the concept of "industrial upgrading" (Gereffi, 1999; Bair and Gereffi, 2001). However, GPNs have more recently widened beyond manufacturing to include sectors such as agro-food and services - e.g. call centres, tourism and business-process outsourcing - where the term "industrial upgrading" is less appropriate. The more generic concept used here is that of economic upgrading which applies across sectors.

There are four types of economic upgrading, each with different implications for skill development and jobs:

- Process upgrading involves changes in the production process with the objective of making it more efficient; this can be achieved by substituting capital for labour - i.e. higher productivity through automation - and thereby reducing skilled or unskilled work.

- $\quad$ Product upgrading occurs where more advanced product types are introduced, which often requires more skilled jobs to make an item with enhanced features.

1 On this point, see the article by William Milberg and Deborah Winkler in this Special Feature of the International Labour Review. 
Functional upgrading occurs where firms change the mix of activities they perform towards higher value added tasks. In the apparel industry, for example, the inclusion of finishing, packaging, logistics and transport can be done in at least two distinct ways: via vertical integration, which adds novel capabilities to a firm or an economic cluster; or via specialization, which substitutes one set of activities for another (e.g. an apparel firm that moves out of production and into brand marketing and design). In electronics, this can happen when firms move from simple assembly to contract manufacturing by engaging in full-package production or to original design manufacturing by developing their own design. Both involve new workforce skill sets linked to expanded firm capabilities.

- Chain upgrading - i.e. shifting to a more technologically advanced production chain - involves moving into new industries or product markets, which often utilize different marketing channels and manufacturing technologies. This may also require a different workforce or innovations that allow existing manufacturers to enter new industries as end markets (such as textile firms shifting from traditional fabrics, like denim for apparel, to specialty nanofibers and strong lightweight materials that can be used in the medical, defence or aircraft industries).

Each type of economic upgrading embodies a capital dimension and a labour dimension. The capital dimension refers to the use of new machinery or advanced technology. The labour dimension refers to skill development or to increased dexterity and productivity on the part of workers. In this formulation, labour is considered primarily as a productive factor determining the quantity and type of employment.

Social upgrading, by contrast, is the process of improvement in the rights and entitlements of workers as social actors, which enhances the quality of their employment (Rossi, 2011; Sen, 1999 and 2000). This includes access to better work, which might result from economic upgrading (e.g. worker who has acquired skills in one job is able to move a better job elsewhere in a GPN). But it also involves enhancing working conditions, protection and rights. Improving the well-being of workers can also help their dependants and communities. The concept of social upgrading is framed by the ILO's Decent Work Agenda, which encompasses employment, standards and rights at work, social protection and social dialogue. This package promotes work performed under conditions of freedom, equity, security and human dignity, in which rights are protected and adequate remuneration and social coverage are provided (ILO, 1999). Economists have long established methods for quantifying the upgrading of labour through measures of labour productivity and skill, but not all aspects of social upgrading are as easily quantifiable.

Social upgrading can be subdivided into two components: measurable standards and enabling rights (Elliott and Freeman, 2003; Barrientos and Smith, 2007). Measurable standards are those aspects of worker well-being that are more easily observable and quantifiable, including type of employment (regular or irregular), wage level, social protection and working hours. They can also in- 
clude data on sex and unionization, such as the percentage of female supervisors or the percentage of union members in the workforce. However, measurable standards are often the outcome of complex bargaining processes, framed by the enabling rights of workers. These are less easily quantified, such as freedom of association, the right to collective bargaining, non-discrimination, voice and empowerment. Lack of access to enabling rights undermines the ability of workers - or specific groups of workers, such as women or migrants - to negotiate improvements in their working conditions that can enhance their well-being.

It is often implicitly assumed that economic upgrading in value chains automatically translates into social upgrading through better wages and working conditions (Knorringa and Pegler, 2006). However, case studies provide a mixed picture. While social upgrading can be the outcome, it may be thwarted if the employment created is highly insecure and exploitative. A vivid but tragic example where apparent economic upgrading failed to translate into comparable social upgrading is that of the Foxconn factory in China, which became associated with multiple worker suicides. Since 2005, China has become the world's largest exporter and producer of mobile phones. Supplying Apple, Nokia and other prominent global electronics brands, Foxconn, a Taiwanese contract manufacturer, has emerged as the largest private employer in China, with over one million workers across more than a dozen factories. The availability of jobs, however, has not necessarily led to social upgrading for Foxconn's workers. Excessive working hours, involuntary and often unpaid overtime work, lack of adequate safety measures, and military-style management practices led to growing discontent among young migrant workers, culminating in a series of suicide attempts that claimed 17 workers' lives during the first eight months of 2011 (SACOM, 2010). However, the links between economic and social upgrading/downgrading are often complex, with different workers experiencing different outcomes on the same production site, as shown by the example from the Moroccan garment industry reported below.

\section{Framework for linking economic and social upgrading in GPNs}

A number of factors can affect the economic and social upgrading (or downgrading) of firms and workers. These include their position within the value chain, the type of work performed, and the status of workers within a given category of work. This section provides a framework for identifying different types of work across GPNs, highlighting key elements of economic and social upgrading for each category. This schema will be used to analyse possible trajectories of economic and social upgrading in the next section.

\section{Typology of work in agro-food, apparel, IT and services GPNs}

When discussing upgrading from a GPN perspective, it is important to emphasize that the unit of analysis is not the individual country, firm or worker, but the 
value chain (linking primary production, processing, distribution and retail) within which firms and workers are located. GPNs are constituted by a mix of activities that require combinations of labour-intensive, low-skilled activities with knowledge- and technology-intensive higher-skilled activities. Different types of GPNs are likely to be composed of different ratios of both low-skill and high-skill production, therefore requiring a comprehensive typology of work. Here we outline different types of work performed within GPNs.

\section{Small-scale household and home-based work}

Small-scale, household-based work is found in many GPNs with operations in developing countries. This type of work is typically performed by small-scale producers or outgrowers involved in agricultural production, and homeworkers in more labour-intensive or artisanal types of manufacturing. These workers usually have access to their own assets and means of subsistence, and are often (but not always) located in poorer countries and regions. Production takes place in or around the household residence, with limited separation between commercial productive activity (producing saleable goods) and unpaid reproductive activity (e.g. household subsistence and childcare). Small-scale production and home-based work involve both paid and unpaid family labour, often including child labour. Homeworkers and small-scale producers are linked into GPNs through very different types of commercial arrangements. In small-firm economies like Taiwan's, homeworking was often the initial stage in the development of what later became factory-based export production in buyer-driven commodity chains for consumer goods industries, such as garments, toys and sporting goods (Hamilton and Gereffi, 2009; Feenstra and Hamilton, 2006; McCormick and Schmitz, 2002).

\section{Low-skilled, labour-intensive work}

Labour-intensive production involving the use of wage labour in a formal factory setting is clearly distinct from household-based production. It involves a relationship based on wage employment between an employer (who may be the producer or an agent) and a worker (normally paid in cash, but sometimes in kind). Global brands and retailers have been able to reduce costs and spread their market reach through outsourcing to lower-cost developing countries. This stimulated the expansion of production and employment linked to GPNs. In manufacturing, since the first offshoring wave in the 1960s and 1970s, the nature of outsourced work has evolved. Whereas the first-generation maquila jobs based on the assembly of garments in Mexico were quite labour-intensive, subsequent generations oriented to the assembly of automotive parts and advanced electronics have often involved substantial automation. As one moves from apparel to auto-parts to electronics, the very nature of assembly work changes to second- and third-generation maquila work. This explains why workers in a given industrial district - e.g. Torreon, Tijuana or Ciudad Juarez in Mexico - often earn higher wages when they move from apparel to auto-parts to electronics (Bair and Gereffi, 2001; Carrillo, 1998). 
China's phenomenal export success during the past two decades can also be linked to a variety of labour-intensive production arrangements - e.g. government-created Special Economic Zones and more locally rooted but highly specialized industrial districts - which have quite different implications for both economic and social upgrading. Recently, China has begun to adopt explicit policies to improve wages and working conditions in response to worker protests and growing uncertainty about the economic prospects for the country's huge migrant workforce, which could create a strong political mandate for linking economic and social upgrading (Zeng, 2010; Gereffi, 2009; Barboza and Tabuchi, 2010).

\section{Medium-skilled, mixed production technologies work}

This type of work is associated with full-package production, driven by the rise of global buyers whose preferred suppliers are required to coordinate all of the operations leading to the delivery of the final good, including design, inputs, production, pre-pricing, packaging and presentation (Gereffi, 1994 and 2005; Dolan and Humphrey, 2000). While global buyers control the orders for full-package production, developing country suppliers coordinate the supply of inputs, make the final product and send it to the buyer. For developing country firms to fill fullpackage orders from global buyers, they need access to varied production technologies and skilled workers capable not only of making key components and finished products, but also of performing production-related service jobs like product design, quality control, packing and logistics, which require a broad range of skills.

\section{High-skilled, technology-intensive work}

High-skilled, technology-intensive work emerged in the 1980s and 1990s from a different set of offshore activities as lead firms in capital- and technologyintensive industries, such as automobiles and electronics, set up international production networks not only to assemble their finished goods, but also to develop a supply base for key intermediate items and sub-assemblies. This form of production is reflected in the rise of global contract manufacturers in the electronics industry and "mega suppliers" in the automotive industry. A dramatic but not atypical example from electronics is Celestica, which spun off from IBM in 1996. From two initial production locations in Canada and the United States, Celestica grew to nearly 50 factories across Asia, Europe and the Americas by 2001 (largely via acquisitions), increasing its sales from $\$ 2$ billion to $\$ 10$ billion during this period (Sturgeon and Lester, 2004, pp. 47-49). At the uppermost tiers of these production networks, the suppliers tend to be very large and technologically sophisticated, and they concentrate "good" jobs in relatively few locations. However, as shown in the case of Foxconn above, global contract manufacturers may also hire large numbers of workers in highly labour-intensive jobs

\section{Knowledge-intensive work}

Knowledge-intensive work in GPNs is being driven by a new wave of offshoring in services (Gereffi and Fernandez-Stark, 2010). Although white-collar outsourcing 
Figure 1. Typology of workforce composition across different GPNs

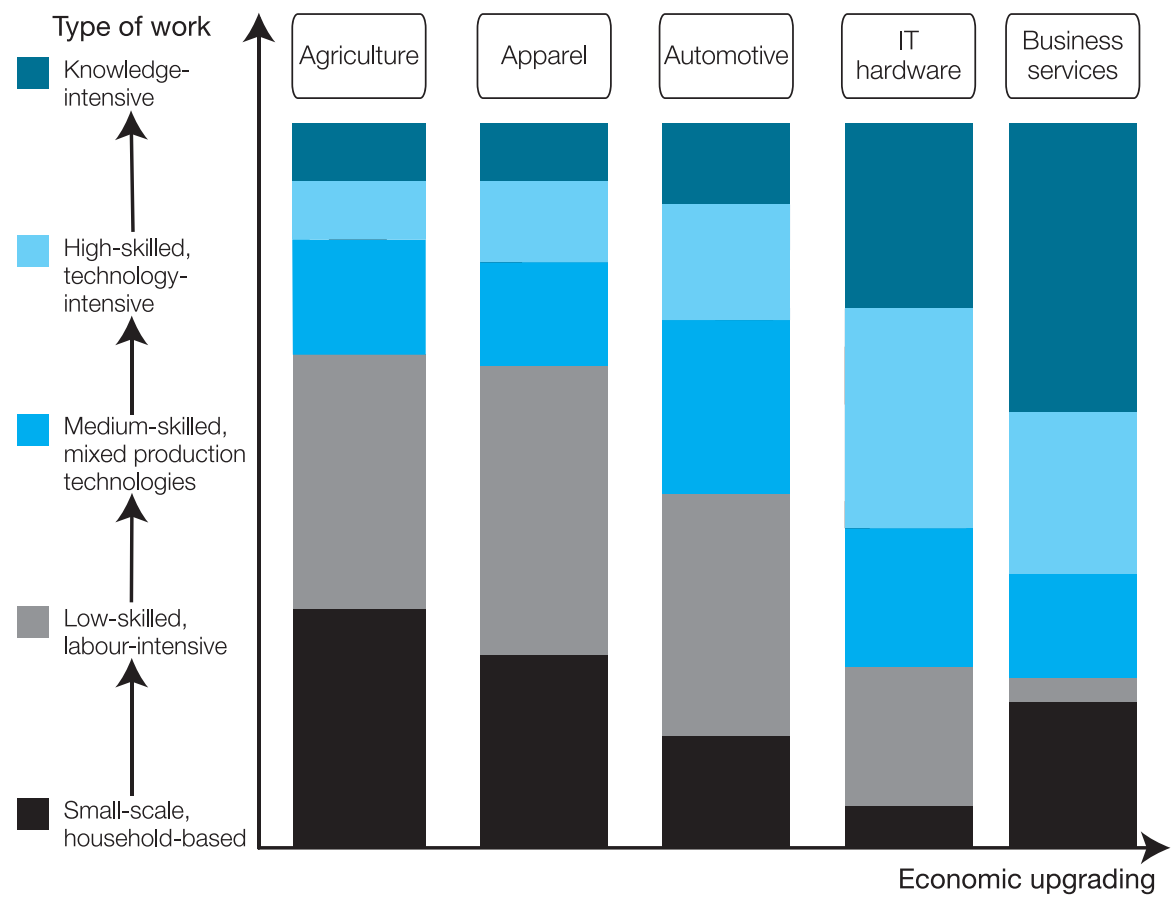

started with simple service jobs like call centres and telemarketing, it now includes more advanced business services such as finance, accounting, software, medical services and engineering. Knowledge-intensive service jobs are increasingly seen as an opportunity for developing economies to reap both economic and social benefits from technological learning, knowledge spillovers, and higher incomes. On average, however, the volume of employment in this work category is relatively small on account of its requirements for high skills and advanced degrees, mainly in science and engineering. Accordingly, the unskilled or less welleducated majority in many countries is excluded from the very desirable employment opportunities provided by knowledge-intensive work.

Based on a simplified typology identifying five GPNs that combine labourintensive, low-tech manufacture, medium-tech manufacture, technology-intensive and knowledge-intensive activities, figure 1 shows how different GPNs incorporate different types of work and skill levels. While all five types of work are represented in each GPN, there are significant differences in the proportions of each type of work across these sectors. Agro-food involves a relatively large proportion of small-scale and low-skill labour-intensive production, particularly at the farm level. Within manufacturing, if we compare industries that can be classified as relatively low-tech (apparel), medium-tech (automotive) and high-tech (electronics), the proportion of low-skilled and household-based types of work decreases, and the relative importance of knowledge-intensive and high-skilled 
work increases. This progression in the nature of the work involved is associated with economic upgrading: as we move to more technology- and knowledgeintensive GPNs, such as IT, labour-intensive production does not disappear but becomes relatively less prominent. However, there is no systematic connection between the proportion of labour-intensive work and social upgrading.

\section{Status of workers}

The type of work undertaken at any point within a GPN has to be further unpacked. Here we draw on Rossi's (2011) case study of economic and social upgrading in the Moroccan garment industry to show that the status of workers can have important implications for their ability to benefit from or participate in economic and social upgrading. Empirical data collected through semi-structured manager interviews and focus group discussions with workers show that the workforce in supplier factories participating in garment GPNs is far from homogeneous. ${ }^{2}$ In response to lead firm requirements in terms of low cost, short lead times, flexibility for last-minute changes in orders, and high quality, which characterize the fast-fashion buyers sourcing from Morocco, ${ }^{3}$ supplier firms resort to employing two different categories of workers. The first consists of regular workers, who are senior and experienced, thereby guaranteeing high skills and good quality. They are usually employed on permanent contracts (albeit often oral contracts based on trust), and they are paid a premium over the minimum wage. The second category consists of irregular workers who are employed in the unskilled segments of the production chain, typically the most time-sensitive, such as packaging and loading trucks. These unskilled workers are usually young women, often internal migrants, who are frequently discriminated against, not covered by any formal contract, paid below the minimum wage, and not covered by any type of social protection.

These two categories of workers face very different opportunities for social upgrading. Regular workers with strong employer attachment can more easily access statutory employment protection and benefit from measurable labour standards. Their greater security of employment may increase their ability to participate in workplace-based trade union organizations and reduce their fear of reprisals, thus enhancing their enabling rights. Irregular workers, with their weak employer attachment, are less able to avail themselves of employer-based protection or measurable standards. Since irregular workers are over-represented among women and ethnic and migrant groups, they often face double discrimination on account of both their social and their employment status. Irregular

2 Interviews and focus group discussions were carried out in a sample of 19 factories in Casablanca, Rabat, Fez and Tangiers in 2008 (Rossi, 2010 and 2011).

3 The fast-fashion segment of the apparel GPN was pioneered by the Spanish brand Zara (which belongs to the Inditex group). The business strategy associated with fast fashion is based on extremely flexible production which follows the latest fashion trends. A garment is produced within two weeks of its design in Spain. Thanks to its proximity to Spain, Morocco has emerged as a key sourcing platform for Zara (Plank, Rossi and Staritz, 2011). 
workers in any type of job are therefore more likely to suffer a "decent work deficit", which denies them access to enabling rights and undermines their relative ability to reap the benefits of economic and social upgrading.

A related but under-researched issue is the role of third-party labour contractors as a channel for recruiting and employing irregular workers in global production. Research by Barrientos (2011) on the garment industry in India and horticulture in South Africa and the United Kingdom indicates that such contracting is increasingly prevalent in the labour-intensive nodes of GPNs involving footloose or seasonal production, such as agro-food and apparel. Labour contracting can involve multiple types of relationship between the producing firm, the contractor and the worker (e.g. payment by the number of workers where the contractor takes a percentage, or payment by task, such as clearing a field). Contractors move groups of workers between sites and locations depending on the season and shifts in demand for labour. They play an increasingly important role in matching "the right type" of workers to tasks, in coordinating labour supply to firms on a "just-in-time" basis (Rogaly, 2008), and in channelling migrant labour (internal and international) to production locations (Martin, 2006). Labour contracting also allows firms to offset production or market risks and minimize labour costs (as well as associated human resource management needs). Such contracting can help workers enhance their continuity of employment between different producers and provide some form of protection in sectors where there are seasonality or "just-in-time" pressures. But it can also open up space for unscrupulous agents who expose workers to high levels of exploitation both on and off site, thereby undermining decent work conditions (Barrientos and Kritzinger, 2004; Kuptsch, 2006; Theron and Godfrey, 2000; Theron et al., 2004). Barrientos (2011) finds that this can include new forms of bonded and forced labour at the heart of global production. Thus the role of labour contractors can significantly affect the relationship between economic and social upgrading, and their workers can be vulnerable to extreme forms of exploitation.

\section{Factors contributing to economic and social upgrading or downgrading}

The different types of work and status of employment provide the context for social upgrading, highlighting the interplay between economic and social upgrading. Table 1 provides an initial overview of how the two are related in these different contexts. Social upgrading is mainly represented by measurable standards, although future work in this area should also utilize research tools to assess the existence and effectiveness of enabling rights. Case study evidence suggests that certain aspects of social upgrading/downgrading, such as flexibility, vulnerability, discrimination, voice and empowerment, cut across the types of work and thus characterize household-based work and knowledge-intensive work alike.

A number of early case studies highlighted problems of poor working conditions and lack of access to decent work (Smith et al., 2004; Collins, 2003; Hale and Wills, 2005; Raworth, 2004). Conditions vary by sector and product, but 


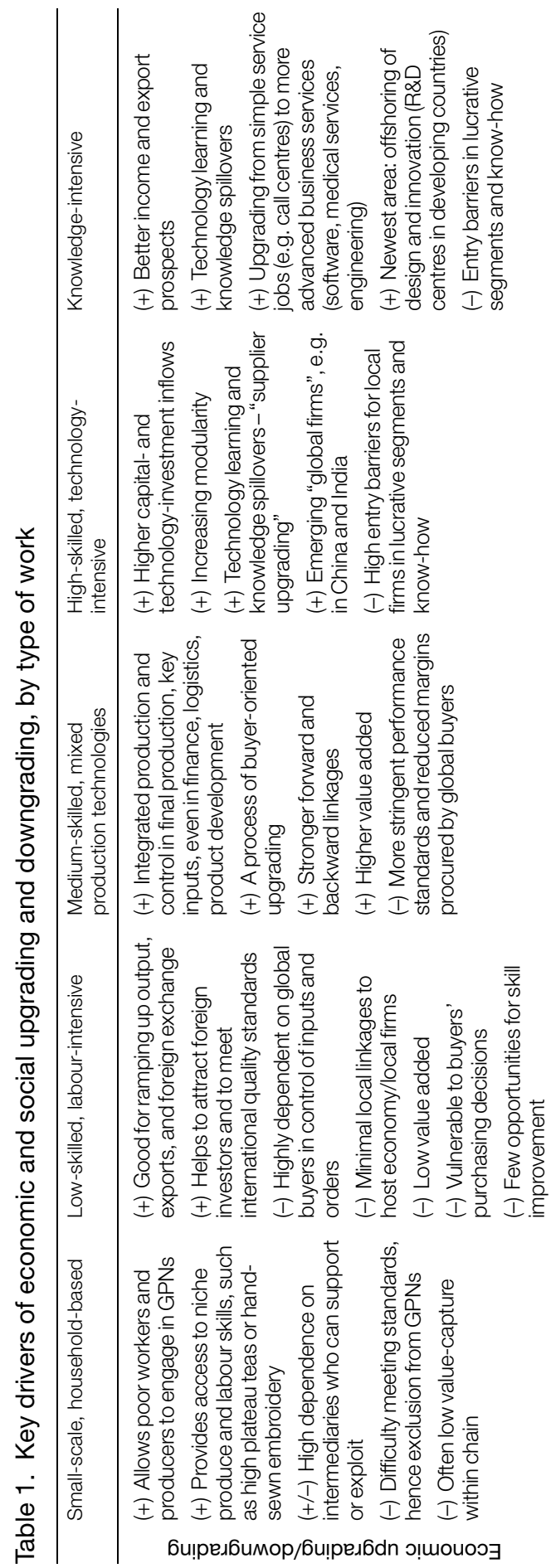

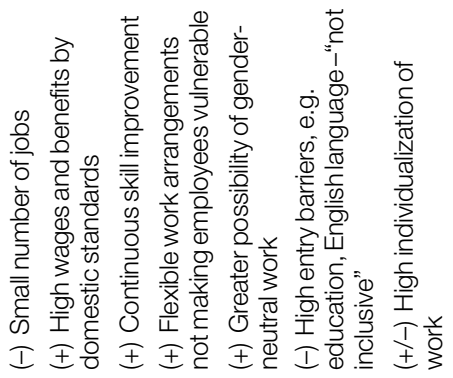

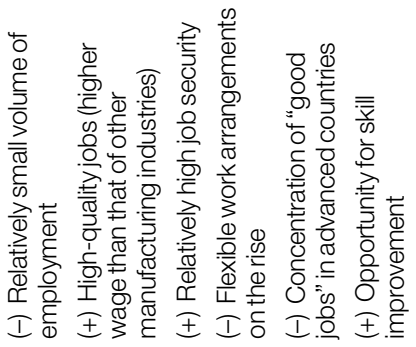

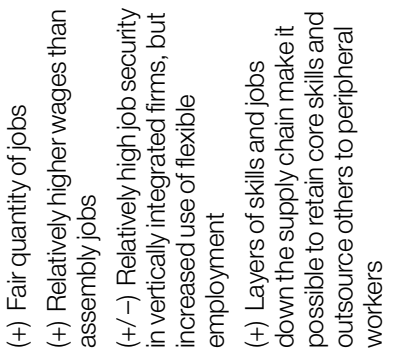

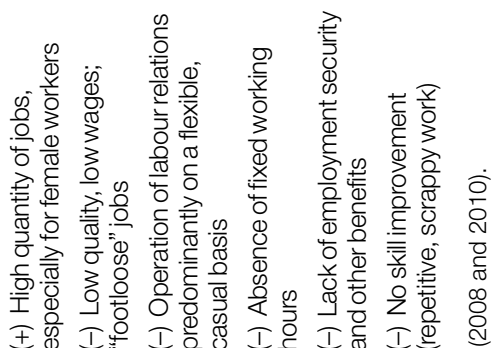

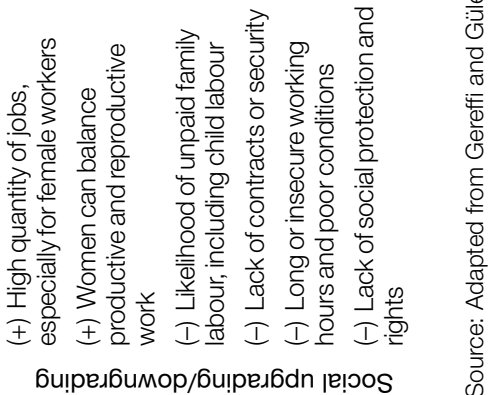


mainly in relation to whether employment is regular or irregular. Labour conditions are consistently found to be better among permanent workers than among temporary and casual workers. Gender bias has also been found to play an important role: Women are preferred by many employers for their perceived dexterity and "nimble fingers" (Elson and Pearson, 1981). However, they tend to perform the insecure and low-paid work, often in temporary or seasonal employment arrangements (Barrientos and Kritzinger, 2004), while men typically occupy the better-paid and more skilled jobs. The position of workers in different nodes of GPNs also plays a role in their overall labour conditions. In manufacturing, for example, conditions are likely to be better in the factory of a preferred supplier that is regularly audited than in a subcontracted firm further down the chain that goes unmonitored (Locke et al., 2007).

Social upgrading may occur for some workers but not for others working in the same factory. Evidence from Morocco's garment industry shows that highskilled workers - even those employed in factories in the cut-make-trim segment of the apparel GPN - may have opportunities for social upgrading, especially in terms of measurable standards, when lead firms are preoccupied with their brand reputation and require compliance with labour standards in their supplier factories. At the same time, unskilled workers may be largely excluded from social upgrading in order for the factory to remain cost-competitive and flexible in terms of last-minute changes in orders. The challenges of social upgrading remain significant for irregular workers even as factories shift their production towards higher value added items. Indeed, the new activities taken on by the factory as a result may well lead to social upgrading for regular workers - through the development of more skills and training for new capabilities - but irregular workers continue to be needed in order to respond to buyers' requirements in terms of low cost, short lead times and high flexibility; their very status impedes their social upgrading.

\section{Trajectories in economic and social upgrading}

As indicated previously, economic upgrading does not necessarily lead to social upgrading (Brown, 2007, Locke et al., 2007). Research (often by civil society organizations) has highlighted the adverse role company purchasing practices can play, with negative outcomes for the workers engaged in GPNs (Insight Investment/Acona, 2004; Raworth, 2004; Oxfam International, 2010; CAFOD, 2004; Barrientos and Kritzinger, 2004). However, this needs to be investigated further by exploring the conditions under which economic upgrading may lead to social upgrading or downgrading.

There are competing pressures for each of these two outcomes within GPNs as suppliers balance higher quality with lower cost. For example, if economic upgrading requires high and consistent quality standards that are best provided by a stable, skilled and formalized labour force, then economic and social upgrading may be positively correlated, especially when they increase worker productivity. This is particularly true of process upgrading, which refers to improved efficiency 
of the production process and is therefore closely linked to an efficient use of labour as a human resource. At the same time, pressures to reduce costs and increase flexibility might lead employers to combine economic upgrading with social downgrading (for example, by outsourcing employment to an exploitative labour contractor), although this raises questions about commercial sustainability if quality is to be assured.

Rossi's (2011) case study of GPN garment factories in Morocco led by fastfashion buyers shows that functional upgrading brings about social upgrading and downgrading simultaneously, for regular and irregular workers, respectively. On the one hand, factories supplying a finished product and overseeing packaging, storage and logistics for their buyers offer stable contracts and better social protection to their high-skilled workers to ensure a continuous relationship as well as full compliance with buyers' codes of conduct. On the other hand, in order to be able to respond quickly to buyers' frequently changing orders and to operate on short lead times, they simultaneously employ irregular workers on casual contracts, especially in the final segments of the production chain (such as packaging and loading), often imposing excessive overtime as well as discriminating against them on the basis of wages and treatment (Rossi, 2011).

To maintain or advance their position in GPNs, suppliers have to engage in a balancing act between maximizing quality (to meet buyers' standards) and minimizing costs/prices (to remain competitive to buyers). This has important implications for labour and the potential for social upgrading. In response to commercial pressures, suppliers' labour strategies can take a "low road" involving economic and social downgrading, a "high road" involving economic and social upgrading, or a mixed approach (see the article by William Milberg and Deborah Winkler in this Special Feature of the International Labour Review). Those taking a low-road approach based on worsening labour conditions risk losing out on quality. Those taking a high-road approach by improving wages and labour conditions risk losing out on price competitiveness. Many producers therefore adopt a mixed approach of high quality and low-cost employment which facilitates both standards and cost flexibility. This is reflected in the simultaneous use of regular and irregular workers on any given site.

Analysing economic and social upgrading trajectories involves understanding that economic upgrading is not always the most appropriate strategy for longterm sustainability. Such strategic decision-making depends largely on the characteristics of the actors. One identified path of upgrading from integrated or "full-package" production activities - also known as original equipment manufacturing $(\mathrm{OEM})$ - to original design manufacturing (ODM) and original brand name manufacturing (OBM) has been very beneficial for some firms in GPNs, including a number of East Asian apparel companies (Gereffi, 1999). However, it cannot work for everyone because risk and competition are much higher in the more advanced segments of GPNs. Some firms choose to remain in their more secure niche of OEM without attempting to upgrade further. For these firms, economic "downgrading" becomes a business strategy. In the computer industry of Taiwan (China), Acer decided it could upgrade by developing its own brand of 
computers, and was successful in doing so; its competitor, Mitac, initially opted to pursue an OBM strategy as well, but soon returned to OEM where the profits were lower, but more secure (Gereffi, 1995, pp. 131-132).

Another example of tactical downgrading occurs in the highly competitive South African wine value chain, where some wine makers were shown to prefer a lower position on the price and quality pyramid for wines exported to the European market. Indeed, some strategies of product and functional "downgrading" - such as selling higher volumes of basic quality or bulk wines rather than premium wines, vertical disintegration by moving away from the high fixed costs of grape growing, and reduced emphasis on premium brands - have enabled firms to maintain stable market shares and margins for mid-range or basic wines, especially during the economic crisis when cost cutting was necessary for survival in some segments of the industry (Ponte and Ewert, 2009). While these strategies have been associated with certain forms of social downgrading, such as reduced lead times and the increased casualization of labour, tactical downgrading in selected areas of the value chain can permit forms of upgrading when economic conditions improve. In short, suppliers in developing economies can adopt mixed strategies of moving up and down the value chain according to domestic and international conditions.

The garment industry in eastern and central Europe (ECE) provides an excellent example of how upgrading and downgrading trajectories have been intertwined. In the early 1980s, some of the ECE economies began to carry out outward-processing trade (OPT) for markets in western Europe, primarily with German buyers and contractors. Given their legacy of established industrialization, the emphasis on apparel exports might be considered economic downgrading. Within the apparel industry, more advanced economies like Slovakia's were able to move more quickly from OPT to full-package export production, and eventually to ODM and OBM, while less developed economies such as Bulgaria's had far more difficulty moving beyond basic OPT contracting. In the ECE economies, however, it was often easier to develop ODM and OBM upgrading strategies for the domestic retail market, than for the more discriminating fastfashion markets of western Europe (Pickles et al., 2006; Evgeniev and Gereffi, 2008).

With regard to social upgrading, certain choices might be considered social "downgrading" for some actors, but not for others. For example, in agriculture the choice to move from a smallholder job to wage employment in a farm might be regarded as an example of social downgrading, due to loss of independence and access to land. However, if the person making this choice is a woman who used to be an unpaid family worker, the move to wage employment can represent an improvement in terms of access to wages. Research on Senegal's horticultural industry found that some small-scale producers were able to comply with European supermarket standards, and that both they and wage workers on large estates received better incomes than small-scale producers unable to enter the supply chains (Maertens and Swinnen, 2009). In order fully to understand economic and social upgrading trajectories, it is important 
Figure 2. Possible social upgrading trajectories

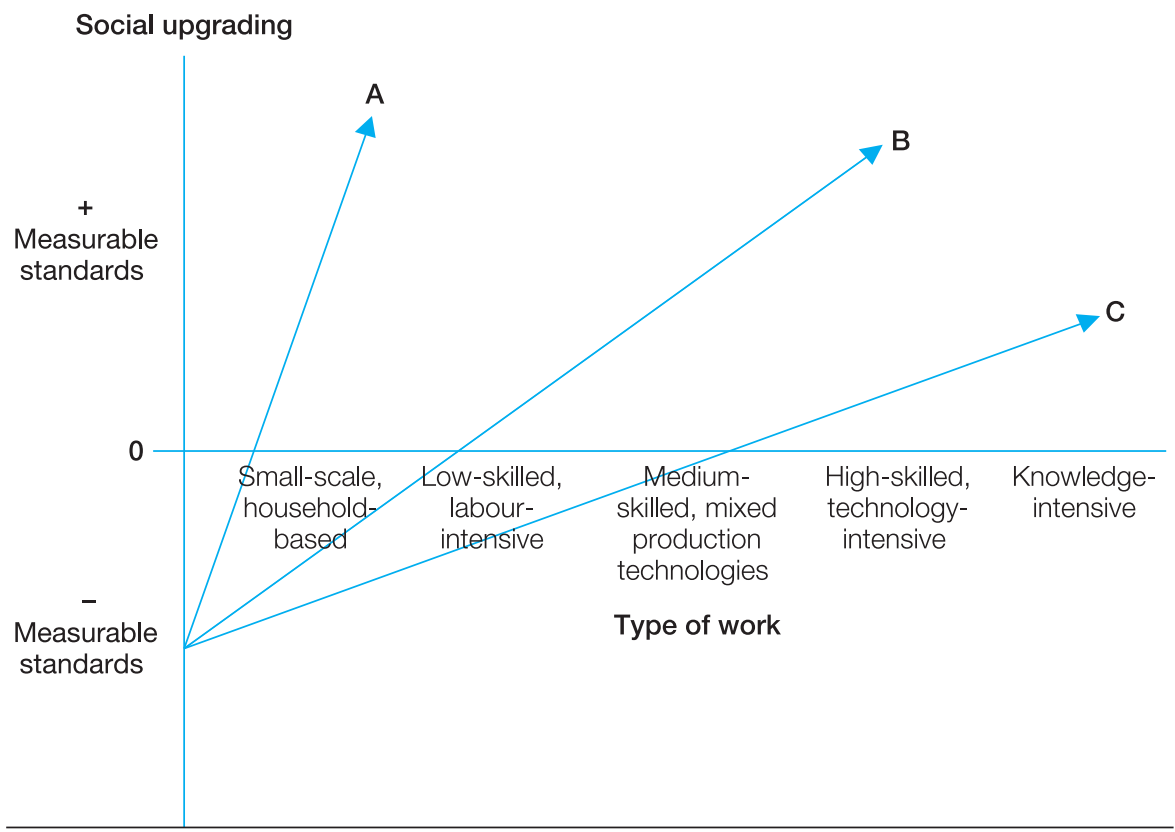

to keep in mind the social context and profile of the different actors involved, which can vary between countries and sectors.

Figure 2 illustrates implications for decent work by portraying three possible trajectories. The horizontal axis sets out the different types of work, from small-scale household-based production, through low- and medium-skilled jobs to high-skilled technology- and knowledge-intensive work. The vertical axis represents social upgrading, according to the measurable standards discussed above. Enabling rights are, by their very nature, not quantifiable in a chart of this form. Recognizing the limitations of figure 2, being located below zero (the horizontal axis) in the diagram constitutes a "decent work deficit" for any given type of work, while being above zero represents levels of "decent work attainment" for any given type of work: the further above zero, the greater the social upgrading gains achieved.

The social upgrading trajectories presented in figure 2 depict a range of possible situations:

A. Small-scale worker upgrading occurs where workers remain within homebased production (agriculture or manufacturing), but are still able to enjoy improvements in their working conditions. For example, it is possible for improvements to occur for those working in small-scale horticulture in Africa, through the establishment of producer organizations and provision of more secure contracts, better pay and personal health and safety equipment. 
B. Labour-intensive upgrading occurs where workers move to better types of labour-intensive work where they can also obtain better working conditions. In Bangladesh or Sri Lanka, for example, women who have migrated from subsistence farming to wage employment in the garment industry may be able to obtain jobs in factories that have implemented buyers' codes of labour practice.

C. Higher-skill upgrading occurs where workers move towards better types of paid employment associated with progressive social upgrading. For example, workers in India or China who have gained sufficient education and training can move from low-paid low-skilled work into the IT sector and, at the same time, obtain higher-paid employment in firms where labour standards are improving.

Case study evidence suggests that a shift from lower to higher skilled types of work may directly lead to social upgrading, but not always. The challenge, therefore, is how to pursue strategies that will enhance labour standards for all workers in all types of work.

Research to date, including the findings from the garment industry in Morocco presented in this article, indicates that the main improvements generated by GPNs in terms of measurable standards and enabling rights tend to be limited to regular workers, i.e. those in stable, usually permanent jobs with a high degree of attachment to their employers. However, extending such improvements to irregular workers, such as casual, migrant and contract workers poses serious challenges. There are indications that the underlying constraints are structurally embedded, as suppliers use a mix of labour categories to achieve both quality and flexibility of output as required by their buyers: employing regular workers to secure quality and consistency of production and irregular workers to cope with fluctuating orders and downward price/cost pressures.

\section{Concluding remarks}

This article has sought to develop a more systematic framework for analysing economic and social upgrading in GPNs, taking into account the different levels of integration of firms and workers that can exist across industries. Drawing on case studies in a variety of sectors has helped to highlight the issues, but their limitation is that they separately examine either economic or social upgrading/downgrading. Rossi's (2011) case study of the garment industry in Morocco sets out to address this gap by applying a framework for integrated analysis of economic and social upgrading in GPNs. Our approach reveals different economic and social upgrading opportunities, and downgrading risks. By analysing the relationship between economic and social upgrading/downgrading more systematically, we hope to have laid the foundations for future research that incorporates both firms and workers as productive actors as well as social agents with rights.

An important aim is to better understand how and why economic upgrading does not automatically lead to social upgrading, thereby providing a more 
informed basis for designing and promoting interventions that will promote both (the so-called "win-win" scenario). Such interventions - reviewed briefly in the preceding article in this Special Feature based on Mayer and Pickles (2010) - can occur at different levels, including: independent trade union representation of workers; company-level initiatives (including buyer and multistakeholder codes of labour practice); government legislation; and multilateral initiatives (such as ILO and OECD guidelines). A key topic for future GPN research is how to design cross-border interventions that yield benefits for poor workers and firms linked through their involvement in the same GPN, but located in different countries.

\section{References}

ActionAid International. 2005. Power hungry: Six reasons to regulate global food corporations. London, ActionAid. Available at: http://www.actionaid.org.uk/_content/documents/ power_hungry.pdf [accessed 5 Jan. 2012].

Bair, Jennifer. 2009. "Global commodity chains: Genealogy and review", in Jennifer Bair (ed.): Frontiers of commodity chain research. Stanford, CA, Stanford University Press, pp. 1-34.

-; Gereffi, Gary. 2001. "Local clusters in global chains: The causes and consequences of export dynamism in Torreon's blue jeans industry", in World Development, Vol. 29, No. 11, pp. 1885-1903.

Barboza, David; Tabuchi, Hiroko. 2010. "Power grows for striking Chinese workers", in New York Times, 8 June, p. B1.

Barrientos, Armando; Ware Barrientos, Stephanie. 2002. Extending social protection to informal workers in the horticulture global value chain. Social Protection Discussion Paper No. 0216. Washington, DC, World Bank.

Barrientos, Stephanie. 2011. "Labour chains": Analysing the role of labour contractors in global production networks. BWPI Working Paper No. 153. Manchester, Brooks World Poverty Institute, University of Manchester.

-; Dolan, Catherine; Tallontire, Anne. 2003. "A gendered value chain approach to codes of conduct in African horticulture", in World Development, Vol. 31, No. 9, pp. 1511-1526.

-; Kritzinger, Andrienetta. 2004. "Squaring the circle: Global production and the informalization of work in South African fruit exports", in Journal of International Development, Vol. 16, No. 1, pp. 81-92.

-; Smith, Sally. 2007. "Do workers benefit from ethical trade? Assessing codes of labour practice in global production systems", in Third World Quarterly, Vol. 28, No. 4, pp. 713-729.

Brown, Drusilla K. 2007. Globalization and Employment Conditions Study. Social Protection Discussion Paper No. 0708. Washington, DC, World Bank.

CAFOD. 2004. Clean up your computer: Working conditions in the electronics sector. London. Available at: http://www.cafod.org.uk/var/storage/original/application/phpYyhizc.pdf [accessed 5 Jan. 2012].

Carrillo, Jorge. 1998. "Third-generation maquiladoras? The Delphi-General Motors case", in Journal of Borderlands Studies, Vol. 13, No. 1, pp. 79-97.

CIVIDEP-India/SOMO. 2009. Corporate geography, labour conditions and environmental standards in the mobile phone manufacturing industry in India. Amsterdam, SOMO Centre for Research on Multinational Corporations. Available at: http://cividep.org/ resources/reports [accessed 5 Jan. 2012].

Clean Clothes Campaign. 2009. Cashing in: Giant retailers, purchasing practices, and working conditions in the garment industry. Available at: http://cleanclothes.org/resources/ccc/ working-conditions/cashing-in [accessed 5 Jan. 2012].

Coe, Neil; Jordhus-Lier, David C. 2011. "Constrained agency? Re-evaluating the geographies of labour", in Progress in Human Geography, Vol. 35, No. 2, pp. 211-233. 
Collins, Jane Lou. 2003. Threads: Gender, labor and power in the global apparel industry. Chicago, IL, Chicago University Press.

Cumbers, Andy; Nativel, Corinne; Routledge, Paul. 2008. "Labour agency and union positionalities in global production networks", in Journal of Economic Geography, Vol. 8, No. 3, pp. 369-387.

Dolan, Catherine S.; Humphrey, John. 2004. "Changing governance patterns in the trade in fresh vegetables between Africa and the United Kingdom", in Environment and Planning A, Vol. 36, No. 3, pp. 491-509.

$-;-.2000$. "Governance and trade in fresh vegetables: The impact of UK supermarkets on the African horticulture industry", in Journal of Development Studies, Vol. 37, No. 2, pp. 147-176.

Elliott, Kimberly Ann; Freeman, Richard B. 2003. "The role global labor standards could play in addressing basic needs", in Jody Heymann (ed.): Global inequalities at work: Work's impact on the health of individuals, families, and societies. New York, NY, Oxford University Press, pp. 299-327.

Elson, Diane; Pearson, Ruth. 1981. "Nimble fingers make cheap workers: An analysis of women's employment in third world export manufacturing", in Feminist Review, Vol. 7, No. 1, pp. 87-107.

ETI (Ethical Trading Initiative). 2005. ETI smallholder guidelines: Recommendations for working with smallholders. London. Available at: http://www.ethicaltrade.org/resources/ key-eti-resources/eti-smallholder-guidelines-eng [accessed 5 Jan. 2012].

Evgeniev, Evgeni; Gereffi, Gary. 2008. "Textile and apparel firms in Turkey and Bulgaria: Exports, local upgrading and dependency", in Economic Studies, Vol. 17, No. 3, pp. $148-179$.

Feenstra, Robert C.; Hamilton, Gary G. 2006. Emergent economies, divergent paths: Economic organization and international trade in South Korea and Taiwan. New York, NY, Cambridge University Press.

Gereffi, Gary. 2009. "Development models and industrial upgrading in China and Mexico", in European Sociological Review, Vol. 25, No.1, pp. 37-51.

-.2006 . The new offshoring of jobs and global development. Geneva, ILO.

-.2005. "The global economy: Organization, governance and development", in Neil J. Smelser and Richard Swedberg (eds): Handbook of Economic Sociology. Second edition. Princeton, NJ, Princeton University Press/Russell Sage Foundation, pp. 160-182.

-.1999. "International trade and industrial upgrading in the apparel commodity chain", in Journal of International Economics, Vol. 48, No. 1, pp. 37-70.

-.1995. "Global production systems and Third World development", in Barbara Stallings (ed.): Global change, regional response: The new international context of development. New York, NY, Cambridge University Press, pp. 100-142.

-.1994. "The organization of buyer-driven global commodity chains: How U.S. retailers shape overseas production networks", in Gary Gereffi and Miguel Korzeniewicz (eds): Commodity chains and global capitalism. Westport, CT, Praeger, pp. 95-122.

-; Fernandez-Stark, Karina. 2010. The offshore services value chain: Developing countries and the crisis. World Bank Policy Research Working Paper No. 5262. Washington, DC, World Bank. Available at: http://go.worldbank.org/K28XW86T40 [accessed 5 Jan. 2012].

-; Güler, Esra. 2010. "Global production networks and decent work in India and China: Evidence from the apparel, automotive and information technology industries", in Anne Posthuma and Dev Nathan (eds): Labour in global production networks in India. New Delhi, Oxford University Press, pp. 103-126.

$-;-.2008$. Opportunities and challenges of participation in global production networks for decent work: Evidence from low and high tech industries in India and China. Revised version of paper presented at the ILO workshop held in Bangalore, 18-20 November 2007.

-; Humphrey, John; Sturgeon, Timothy. 2005. "The governance of global value chains", in Review of International Political Economy, Vol. 12, No. 1, pp. 78-104.

-; Kaplinsky, Raphael (eds). 2001. The value of value chains: Spreading the gains from globalisation. Special issue of the IDS Bulletin, Vol. 32, No. 3 (July). 
Hale, Angela; Wills, Jane (eds). 2005. Threads of labour. Oxford, Blackwell.

Hamilton, Gary; Gereffi, Gary. 2009. "Global commodity chains, market makers, and the rise of demand-responsive economies", in Jennifer Bair (ed.): Frontiers of commodity chain research. Stanford, CA, Stanford University Press, pp. 136-161.

Henderson, Jeffrey; Dicken, Peter; Hess, Martin; Coe, Neil; Wai-chung Yeung, Henry. 2002. "Global production networks and the analysis of economic development", in Review of International Political Economy, Vol. 9, No. 3, pp. 436-464.

Hess, Martin; Yeung, Henry Wai-chung. 2006. "Whither production networks in economic geography? Past, present and future", in Environment and Planning A, Vol. 38, No. 7, pp. 1193-1204.

ILO. 1999. Decent Work. Report of the Director-General to the 89th Session of the International Labour Conference. Geneva.

Insight Investment/Acona. 2004. Buying your way into trouble? The challenge of responsible supply chain management. London. Available at: http://www.acona.co.uk/reports/Buying +your+way+into+trouble.pdf [accessed 5 Jan. 2012].

Knorringa, Peter; Pegler, Lee J. 2006. "Globalisation, firm upgrading and impacts on labour", in Tijdschrift voor Economische en Sociale Geografie, Vol. 97, No. 5, pp. 470-479.

Kuptsch, Christiane (ed.). 2006. Merchants of labour. Geneva, International Institute for Labour Studies.

Lee, Joonkoo. 2010. "Global commodity chains and global value chains", in Robert A. Denemark (ed.): The International Studies Encyclopedia. Oxford, Wiley-Blackwell, pp. 2987-3006.

Locke, Richard; Kochan, Thomas; Romis, Monica; Qin, Fei. 2007. "Beyond corporate codes of conduct: Work organization and labour standards at Nike's suppliers", in International Labour Review, Vol. 146, No. 1-2, pp. 21-40.

Maertens, Miet; Swinnen, Joe. 2009. "Trade, standards and poverty: Evidence from Senegal”, in World Development, Vol. 37, No. 1, pp. 161-178.

Martin, Philip. 2006. "Regulating private recruiters: The core issues", in Kuptsch, pp. 13-25.

Mayer, Frederick W.; Pickles, John. 2010. Re-embedding governance: Global apparel value chains and decent work. Capturing the Gains Working Paper No. 2010/1. Available at: http://www.capturingthegains.org/pdf/ctg-wp-2010-01.pdf [accessed 5 Jan. 2012].

McCormick, Dorothy; Schmitz, Hubert. 2002. Manual for value chain research on homeworkers in the garment industry. Brighton, Institute of Development Studies, University of Sussex.

Miller, Doug; Turner, Simon; Grinter, Tom. 2011. Back to the future? A critical reflection on Neil Kearney's mature systems of industrial relations perspective on the governance of outsourced apparel supply chains. Capturing the Gains Working Paper No. 2011/08. Manchester, University of Manchester. Available at: http://www.capturingthegains.org/ pdf/ctg-wp-2011-08.pdf [accessed 5 Jan. 2012].

Oxfam International. 2010. Better jobs in better supply chains. Briefings for Business, No. 5. Oxford. Available at: http://www.oxfam.org/sites/www.oxfam.org/files/b4b-better-jobsbetter-supply-chains.pdf [accessed 5 Jan. 2012].

Pegler, Lee J.; Knorringa, Peter. 2007. "Integrating labour issues in global value chain analysis: Exploring implications for labour research and unions", in Verena Schmidt (ed.): Trade union responses to globalisation: A review by the Global Unions Research Network. Geneva, ILO, pp. 35-51.

Pickles, John; Smith, Adrian; Bucek, Milan; Roukova, Poli; Begg, Robert. 2006. "Upgrading, changing competitive pressures, and diverse practices in the east and central European apparel industry", in Environment and Planning A, Vol. 38, No. 12, pp. 2305-2324.

Plank, Leonhard; Rossi, Arianna; Staritz, Cornelia. 2011. Workers and social upgrading in "fast fashion": The case of the apparel industry in Morocco and Romania. Paper presented to the Better Work Research Conference - Workers, Businesses and Government: Understanding Labour Compliance in Global Supply Chains, Washington, DC, 26-28 Oct.

Ponte, Stefano; Ewert, Joachim. 2009. "Which way is 'up' in upgrading: Trajectories of change in the value chain for South African wine", in World Development, Vol. 37, No. 10, pp. 1637-1650. 
Raworth, Kate. 2004. Trading away our rights: Women working in global supply chains. Oxford, Oxfam.

-; Kidder, Thalia. 2009. "Mimicking 'lean' in global value chains: It's the workers who get leaned on", in Jennifer Bair (ed.): Frontiers of commodity chain research. Stanford, CA, Stanford University Press, pp. 165-189.

Rogaly, Ben. 2008. "Intensification of workplace regimes in British horticulture: The role of migrant workers", in Population, Space and Place, Vol. 14, No. 6, pp. 497-510.

Rossi, Arianna. 2011. Economic and social upgrading in global production networks: The case of the garment industry in Morocco. DPhil dissertation. Brighton, Institute of Development Studies, University of Sussex.

-.2010. The impact of the Fibre Citoyenne label on the Moroccan garment industry and its workers. Paper presented to the Conference on "Social Labelling in the Global Fashion Industry", University of Northumbria, Newcastle, 1-3 Sep.

SACOM. 2010. Workers as machines: Military management in Foxconn. Hong Kong, Students \& Scholars Against Corporate Misbehaviour. Available at: http://sacom.hk/archives/740 [accessed 5 Jan. 2012].

Sen, Amartya. 2000. "Work and rights", in International Labour Review, Vol. 139, No. 2, pp. 119-128.

-.1999. Development as freedom. Oxford, Oxford University Press.

Smith, Sally; Auret, Diana; Barrientos, Stephanie; Dolan, Catherine; Kleinbooi, Karin; Njobvu, Chosani; Opondo, Maggie; Tallontire, Anne. 2004. Ethical trade in African horticulture: Gender, rights and participation. IDS Working Paper 223. Brighton, Institute of Development Studies, University of Sussex.

Staritz, Cornelia; Gereffi, Gary; Cattaneo, Olivier (eds). 2011. "Special Issue: Shifting end markets and upgrading prospects in global value chains", International Journal of Technological Learning, Innovation and Development, Vol. 4, No. 1-3.

Sturgeon, Timothy J.; Lester, Richard K. 2004. "The new global supply base: New challenges for local suppliers in East Asia”, in Shahid Yusuf, M. Anjum Altaf and Kaoru Nabeshima (eds): Global production networking and technological change in East Asia. Washington, DC, World Bank/Oxford University Press, pp. 35-87.

Theron, Jan; Godfrey, Shane. 2000. Protecting workers on the periphery. Cape Town, Institute of Development and Labour Law, University of Cape Town.

-; -; Lewis, Peter; Pienaar, Mimi. 2004. Labour broking and temporary employment services: A report on trends and policy implications of the rise in triangular employment arrangements. Labour and Enterprise Project, Institute of Development and Labour Law, University of Cape Town.

Wilde, Joseph; de Hann, Esther. 2006. The high cost of calling: Critical issues in the mobile phone industry. Amsterdam, SOMO - Centre for Research on Multinational Corporations. Available at: http://somo.nl/html/paginas/pdf/High_Cost_of_Calling_nov_2006_ EN.pdf [accessed 5 Jan. 2012].

Zeng, Douglas Zhihua (ed.). 2010. Building engines for growth and competitiveness in China: Experience with special economic zones and industrial clusters. Washington, DC, World Bank. 